\title{
Physical and Mechanical Properties of Hornbeam Wood from Dominant and Suppressed Trees
}

\section{Fizikalna i mehanička svojstva drva graba dominantnih i potisnutih stabala}

\author{
Preliminary paper • Prethodno priopćenje \\ Received-prispjelo: 23. 1. 2017. \\ Accepted-prihvaćeno: 21. 2. 2018. \\ UDK: $630 * 812.7 ; 630 * .812 .1$ \\ doi:10.5552/drind.2018.1705
}

\begin{abstract}
Physical and mechanical properties are important factors in determining the suitability and application of wood material. This study aimed to investigate physical and mechanical properties of hornbeam wood (Carpinus betulus L.) in dominant and suppressed trees. Disks and logs of wood were cut at breast height to examine physical properties (oven-dried density, basic density, longitudinal shrinkage, tangential shrinkage, radial shrinkage, and volumetric shrinkage) and mechanical properties (static bending, compression strength parallel to the grain, compression perpendicular to the grain and hardness). T-test analysis indicated that forest mass (dominant-suppressed trees) affected the mechanical properties significantly (except modulus of elasticity). No significant difference was found between dominant and suppressed trees in terms of physical properties. MOE and MOR are higher in suppressed trees than in dominant trees. The average values of compression strength parallel to the grain, compression strength perpendicular to the grain and hardness of hornbeam wood were higher in the dominant trees than in the suppressed stands. In terms of mechanical properties of hornbeam wood in suppressed and dominant trees, the quality of wood is fair.
\end{abstract}

Keywords: suppressed trees, dominant trees, hornbeam, physical properties, mechanical properties

SAŽETAK • Fizikalna i mehanička svojstva važni su čimbenici pri određivanju prikladnosti i primjene drvnog materijala. Ova je studija usmjerena na istraživanje fizikalnih i mehaničkih svojstava drva graba (Carpinus betulus L.) dominantnih i potisnutih stabala. Diskovi i uzorci drva izrezani su na prsnoj visini stabla kako bi se odredila fizikalna svojstva (gustoća apsolutno suhog drva, nominalna gustoća drva, uzdužno utezanje, tangencijalno utezanje te radijalno $i$ volumno utezanje) i mehanička svojstva (statičko savijanje, tlačna čvrstoća paralelno s vlakancima, tlačna čvrstoća okomito na vlakanca i tvrdoća). Analiza statističkim T-testom pokazala je da je šumska biomasa dominantnih i potisnutih stabala značajno utjecala na mehanička svojstva drva graba (osim na modul elastičnosti). Međutim, nije zabilježena značajna razlika u fizikalnim svojstvima drva dominantnih i potisnutih stabala. Dobivene vrijednosti MOE i MOR za drvo potisnutih stabala veće su od vrijednosti dobivenih za drvo dominantnih stabala. Prosječne vrijednosti tlačne čvrstoće paralelno s vlakancima, tlačne čvrstoće okomito na vlakanca i tvrdoće grabova drva dominantnih stabala bile su veće u usporedbi s drvom stabala iz potisnutih sastojina. Prema dobivenim vrijednostima mehaničkih svojstava drva može se zaključiti da je drvo graba i dominantnih i potisnutih stabala prosječne kvalitete.

Ključne riječi: potisnuta stabla, dominantna stabla, grab, fizikalna svojstva, mehanička svojstva

\footnotetext{
${ }^{1}$ Authors are associate professor and Ph.D. student at Department of Wood and Paper Science and Technology, Chalous Branch, Islamic Azad University, Chalous, Iran.

Autori su izvanredni profesor i doktorand Odjela za znanost i tehnologiju drva i papira, Chalous Branch, Islamic Azad University, Chalous, Iran.
} 


\section{INTRODUCTION}

\section{UVOD}

The genus Carpinus, belonging to the Betulaceae family, comprises approximately 35 woody species. It occurs widely in Europe, Eastern Asia and North and Central America. Hornbeam is a native, diffuse-porous hardwood species in the Caspian forests; it grows in mixed stands with oak and beech and in some areas with Parrotia persica (Sabeti, 2008). It prefers a warm climate for good growth and is usually found at elevations up to $1000 \mathrm{~m}$ a.s.l. (Kiaei, 2012; Parsapajouh, 1998). Hornbeam has the maximum fiber length among Iranian hardwood species, which is suitable for papermaking industries. According to Garmaroody et al. (2012) and Gunduz et al. (2009), Carpinus betulus L. has a low resistance to insects and fungi.

Because of different lighting needs, reducing competition among trees, and different soil needs, mixed stands are better than pure stands. There are many reports about wood properties and growth of dominant and suppressed hardwood species in Northern Iran. In this direction, Rouhi-Moghaddam et al., (2009) reported that better results were achieved for oak trees in mixed plantations with hornbeam (based on survival, diameter at breast height and H/D ratio) and Siberian elm (based on total height and pruning height), while pure plantations and the plantations mixed with maple showed unsuitable results. Sayad et al., (2006) indicated in a study entitled "Growth and qualitative properties in pure and mixed plantations of Populus deltoides" that poplar trees in mixed plantations had higher diameter at breast height and total height than in pure stands. Jalali et al., (2003) reported that wood density, lignin and extractives contents in mixed plantations of poplar trees were higher than in pure plantations. Also, pure plantations had high cavity diameter and high cellulose content compared to mixed plantations. Kabiri et al. (2009) indicated that the trees heights and trunks length in pure beech stands were significantly higher than in mixed stands.

There are few studies about trees growth in suppressed and dominant stands, such as the studies of Kozlowski and Peterson (1962) and Rathgeber et al., (2011). They reported that dominant trees, which started growing earlier, grew faster, and had a longer grow- ing season than suppressed trees. So far, there has been no information about the variation of wood properties of suppressed and dominant horn beam trees. Therefore, the objectives of this research were: a) to examine physical and mechanical properties of hornbeam wood (Carpinus betulus L.) in dominant and suppressed trees and b) to investigate wood quality according to mechanical properties of hornbeam wood in dominant and suppressed stands.

\section{MATERIALS AND METHODS}

\section{MATERIJAL I METODE}

In this research, 6 samples were randomly selected from dominant ( 3 trees) and suppressed (3 trees) hornbeam (Carpinus betulus L.) trees with straight stem and with no obvious signs of decay from a natural forest at the Behshahr-Mazandran site located in the north of Iran (Table 1). The annual rainfall and average annual temperature in Behshahr site were $480.3 \mathrm{~mm}$ and $13.1^{\circ} \mathrm{C}$. Suppressed hornbeam trees were mixed with Iron (Parrotia persica), and hornbeam dominant trees were mixed with beech (Fagus orientalis). The hornbeam trees growing with beech and Persian iron trees were suppressed trees and dominant trees, respectively. From each of these trees, a log (6 logs in total) $200 \mathrm{~cm}$ in length was cut out at breast height to determine physical and mechanical properties. Mechanical and physical properties were determined and evaluated for mature wood only, as it is more stable than juvenile wood regarding mechanical properties (Figure 1). Previous researches claimed that the age demarcation point between juvenile and mature wood is estimated at round 18 years old (from ring 18 onwards; Makhmalbaf et al., 2007).

\subsection{Physical properties}

2.1. Fizikalna svojstva

In order to determine the physical properties, such as density and shrinkage, samples with dimensions of 25 $\mathrm{mm}$ (long) and $20 \mathrm{~mm} \times 20 \mathrm{~mm}$ (transverse dimensions) were prepared according to ISO-3131 and ISO-4858 (referring to ISO 4469). Then the dimensions of 50 wood specimens (for each physical property) in all 3 directions were calculated and the weights of samples were measured in the first step. In the second step, the specimens

Table 1 Characteristics of the test and trees at the Behshahr site Tablica 1. Podatci o istraživanju stabala iz područja Behshahr

\begin{tabular}{|l|c|c|}
\hline $\begin{array}{l}\text { Properties } \\
\text { Obilježje }\end{array}$ & $\begin{array}{c}\text { Suppressed trees } \\
\text { Potisnuta stabla }\end{array}$ & $\begin{array}{c}\text { Dominant trees } \\
\text { Dominantna stabla }\end{array}$ \\
\hline Stands / Sastojina & $\begin{array}{c}\text { Mixed (hornbeam-beech) } \\
\text { Mješovita (grab - bukva) }\end{array}$ & $\begin{array}{c}\text { Mixed (hornbeam-Iron) } \\
\text { Mješovita (grab - perzijska parocija) }\end{array}$ \\
\hline Altitude, $\mathrm{m}$ / nadmorska visina, $\mathrm{m}$ & 715 & 625 \\
\hline Number of trees / broj stabala & 3 & 3 \\
\hline Tree age, year / starost stabala, god. & 60 & 58 \\
\hline Tree height* / visina stabala & 19.4 & 5.6 \\
\hline Bark, \%* / kora, \% & 7.1 & 94.4 \\
\hline Wood, \%* / drvo, \% & 92.9 & 2.4 \\
\hline Annual ring width, $\mathrm{mm}^{*}$ / širina goda, $\mathrm{mm}$ & 3.1 & \\
\hline
\end{tabular}

* These values are average for all selected trees. / U tablici su navedene prosječne vrijednosti za izabrana stabla. 


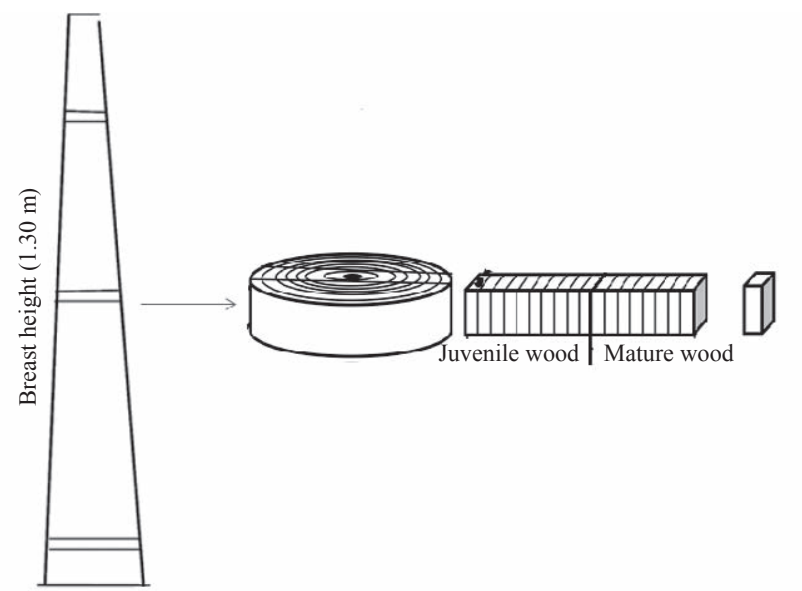

Figure 1 Sawing pattern used on each stem section for the analysis of physical and mechanical wood properties

Slika 1. Prikaz mjesta uzimanja uzoraka sa stabla za analizu fizikalnih i mehaničkih svojstava drva

were placed in distilled water for 72 hours to ensure that moisture content was above the fiber saturation point. Then the dimensions in all 3 principal directions were measured with a digital caliper to the nearest $0.001 \mathrm{~mm}$. Samples were weighed to the nearest $0.001 \mathrm{~g}$ for saturated weight, and the saturated volume was calculated based on these dimensions. In the third stage, the samples were placed in an oven for $72 \mathrm{~h}$, at $103 \pm 2{ }^{\circ} \mathrm{C}$, until the samples dried completely. The volume and weight of the samples were measured in absolutely dry state. The samples were again weighed and the dimensions in all 3 directions were measured. Finally, wood basic density, oven-dry density, longitudinal shrinkage, radial shrinkage, and tangential shrinkage were calculated by specific formulas. The physical properties of the wood measured were basic density (oven-dry weight / saturated volume) and oven-dry density (oven-dry weight / oven-dry volume). Dimensional differences of the samples were used to estimate longitudinal (L), radial $(\mathrm{R})$, tangential $(\mathrm{T})$ and volumetric shrinkage (V) [(saturated - oven-dry dimension)/saturated dimension] x 100.

\subsection{Mechanical properties}

\subsection{Mehanička svojstva}

The mechanical properties of 30 specimens (for each mechanical property) were determined in accordance with ASTM D 143-94 (2000). Regarding this standard, the sample dimensions were $25 \times 25 \times 410$ $\mathrm{mm}$ for static bending strength tests (to determine modulus of rupture and modulus of elasticity), $25 \times 25$ $\times 100 \mathrm{~mm}$ for compression parallel to the grain, and 50 $\times 50 \times 150 \mathrm{~mm}$ for compression perpendicular to the grain and hardness. The samples were conditioned at a temperature of $20{ }^{\circ} \mathrm{C}$ and $65 \pm 5 \%$ relative humidity and they reached equilibrium moisture content of about $12 \%$ (Kiaei, 2013). Then, the wood density was based on the ratio of weight to volume at $12 \%$ moisture content. Four mechanical qualities were determined by the following formulas (Korkut and Guller, 2008; Bektas et al., 2002; Parsapajouh, 1998):

$$
\begin{aligned}
S Q V & =\frac{C P G}{100 \cdot D_{12}} \\
S B I & =\frac{M O R}{100 \cdot D_{12}} \\
S Q & =\frac{M O R}{C P G} \\
q & =\frac{C P G}{D_{0}}
\end{aligned}
$$

Where, $C P G$ is compression parallel to grain, $M O R$ is modulus of rupture, $D_{0}$ is oven-dried density, $S Q V$ is static quality value, $S B I$ is static bending index, $S Q$ is Strong quotation, $D_{12}$ is density at $12 \%$ moisture content.

\subsection{Statistical analysis \\ 2.3. Statistička analiza}

The influence of suppressed-dominant trees on physical and mechanical properties of hornbeam wood at Behshahr-Mazandran site was analyzed by T-test (SPSS statistical software, IBM software, Armonk, New York; Version 20).

\section{RESULTS AND DISCUSSION 3. REZULTATI I RASPRAVA}

\subsection{Physical properties}

3.1. Fizikalna svojstva

\subsubsection{Oven-dry density}

3.1.1. Gustoća apsolutno suhoga drva

T-test analysis indicated that the effect of suppressed-dominant trees on oven-dry density was not significant. The average oven-dry density of hornbeam wood in suppressed and dominant trees was 750 and $740 \mathrm{~kg} / \mathrm{m}^{3}$, respectively. The average value of hornbeam wood in suppressed trees is slightly higher than in dominant tress (Table 2). The mean oven-dry density

Table 2 Physical properties of hornbeam wood

Tablica 2. Fizikalna svojstva drva grabovine

\begin{tabular}{|l|c|c|}
\hline $\begin{array}{l}\text { Physical properties } \\
\text { Fizikalna svojstva }\end{array}$ & $\begin{array}{c}\text { Suppressed } \\
\text { Potisnuta stabla }\end{array}$ & $\begin{array}{c}\text { Dominant } \\
\text { Dominantna stabla }\end{array}$ \\
\hline Oven-dry density / gustoća apsolutno suhoga drva, $\mathrm{kg} / \mathrm{m}^{3}$ & $750 \mathrm{a}$ & $740 \mathrm{a}$ \\
\hline Basic density / nominalna gustoća drva, $\mathrm{kg} / \mathrm{m}^{3}$ & $620 \mathrm{a}$ & $620 \mathrm{a}$ \\
\hline Density at 12\% moisture content / gustoća drva pri 12\% sadržaja vode, $\mathrm{kg} / \mathrm{m}^{3}$ & $790 \mathrm{a}$ & $790 \mathrm{a}$ \\
\hline Lognitudinal shrinkage / uzdužno utezanje, \% & $0.60 \mathrm{a}$ & $0.60 \mathrm{a}$ \\
\hline Radial shrinkage / radijalno utezanje, \% & $6.80 \mathrm{a}$ & $6.70 \mathrm{a}$ \\
\hline Tangential shrinkage / tangencijalno utezanje, \% & $11.85 \mathrm{a}$ & $12.95 \mathrm{a}$ \\
\hline Volumetric shrinkage / volumno utezanje, \% & $19.30 \mathrm{a}$ & $20.30 \mathrm{a}$ \\
\hline
\end{tabular}


in suppressed and dominant trees is higher than in other sites in Iran such as Golestan (Golbabeai et al., 2004), Veysar-Mazandran (Hossinzade et al., 2000), Sangedeh-Sari (Nasernakheai et al., 1997) and Asalom Guilan (intermediate and low altitudes- Golbabeai et al., 2001), and lower than in high altitude of Asalom Guilan site (Golbabeai et al., 2001). The average wood density of Turkish hornbeam wood is the same (Gunduz et al., 2009; Table 3).

\subsubsection{Basic density}

\subsubsection{Nominalna gustoća drva}

T-test analysis indicated that the effect of suppressed-dominant trees on the basic density of hornbeam wood was not significant. The average basic density of hornbeam wood in both suppressed and dominant trees was $620 \mathrm{~kg} / \mathrm{m}^{3}$. The average basic density of hornbeam wood is the same in suppressed and dominant trees (Table 2).

\subsubsection{Density at $\mathbf{1 2} \%$ moisture content}

3.1.3. Gustoća drva pri $12 \%$ sadržaja vode

T-test analysis indicated that the effect of suppressed-dominant trees on wood density was not significant. The average MOR in suppressed and dominant trees was $790 \mathrm{~kg} / \mathrm{m}^{3}$. This average is the same in suppressed and dominant trees (Table 2).

\subsubsection{Longitudinal shrinkage}

\subsubsection{Uzdužno utezanje}

T-test analysis indicated that the effect of suppressed-dominant trees on longitudinal shrinkage was not significant. The average longitudinal shrinkage of hornbeam wood in suppressed and dominant trees was $0.6 \%$. The average longitudinal shrinkage of hornbeam wood is the same in suppressed and dominant trees (Table 2).

\subsubsection{Radial shrinkage}

\subsubsection{Radijalno utezanje}

T-test analysis indicated that the effect of suppressed-dominant trees on radial shrinkage of hornbeam wood was not significant. The average radial shrinkage of hornbeam wood in suppressed and dominant trees was 6.80 and $6.70 \%$, respectively. This average radial shrinkage of hornbeam wood is lower in suppressed trees than in dominant tress (Table 2).

\subsubsection{Tangential shrinkage}

3.1.6. Tangencijalno utezanje

T-test analysis indicated that the effect of suppressed-dominant trees on tangential shrinkage of hornbeam wood was not significant. The average tangential shrinkage of hornbeam wood in suppressed and dominant trees was 11.85 and $12.95 \%$, respectively. This average tangential shrinkage is lower in suppressed trees than in dominant tress (Table 2).

\subsubsection{Volumetric shrinkage}

\subsubsection{Volumno utezanje}

T-test analysis indicated that the effect of suppressed-dominant trees on volumetric shrinkage of hornbeam wood was not significant. The average volumetric shrinkage of hornbeam wood in suppressed and dominant trees was 19.30 and $20.30 \%$, respectively. This average volumetric shrinkage is lower in suppressed trees than in dominant tress (Table 2).

There are three classifications (Parsapajouh, 1998) according to volumetric shrinkage, low (until 15 $\%$ ), median (15-20\%) and high shrinkage (above 20 $\%)$. Therefore, the volumetric shrinkage of hornbeam in suppressed and dominant trees falls under the second and third category. According to the results, hornbeam wood has a high volumetric shrinkage, which can be considered as a disadvantage of hornbeam wood.

\subsection{Mechanical properties}

3.2. Mehanička svojstva

\subsubsection{Modulus of rupture (MOR)}

\subsection{1. Čvrstoća loma (MOR)}

T-test analysis indicated that the effect of suppressed-dominant trees on the MOR of hornbeam wood was significant. The averag MOR in suppressed and dominant trees was 153.5 and $140.9 \mathrm{MPa}$, respec-

Table 3 Comparison of wood properties of Behshahr site (this study) with other sites

Tablica 3. Usporedba svojstava drva iz područja Behshahr sa svojstvima drva iz drugih sastojina

\begin{tabular}{|l|l|c|c|c|c|c|c|c|}
\hline Site / Područje & $\mathrm{A}$ & $\mathrm{B}$ & $\mathrm{C}$ & $\mathrm{D}$ & $\mathrm{E}$ & $\mathrm{F}$ & $\mathrm{G}$ \\
\hline \multirow{3}{*}{ Aslom Guilan } & High altitude / viša nadmorska visina & 790 & - & - & - & - & - & - \\
\cline { 2 - 9 } & Intermediate / srednja n. v. & 730 & 130.52 & 15.60 & 41.36 & - & - & - \\
\cline { 2 - 8 } & Low / niža n. v. & 700 & - & - & - & - & - & - \\
\hline \multirow{2}{*}{ Golestan } & High altitude / viša nadmorska visina & 723 & 104.1 & 10.51 & 63.27 & - & - & 12.30 \\
\cline { 2 - 8 } & Intermediate / srednja n. v. & 711 & 116.26 & 11.74 & 70.63 & - & - & 13.75 \\
\hline \begin{tabular}{l} 
Veysar-Mazandran \\
\hline Sangedeh-Sari- Mazandran
\end{tabular} & 736 & 101.47 & 14.44 & 38.75 & - & - & - \\
\hline $\begin{array}{l}\text { Supressed trees (present study) } \\
\text { potisnuta stabla (rezultati ovih istraživanja) }\end{array}$ & 750 & 153.5 & 14.76 & 63.2 & 91.8 & 75 & 9.7 \\
\hline $\begin{array}{l}\text { Dominant trees (present study) } \\
\text { dominantna stabla (rezultati ovih istraživanja) }\end{array}$ & 740 & 140.9 & 14.70 & 64.5 & 97.8 & 84.1 & 11.50 \\
\hline \begin{tabular}{l} 
Turkey \\
\hline
\end{tabular}
\end{tabular}

A - oven-dry density / gustoća apsolutno suhog drva, $\mathrm{kg} / \mathrm{m}^{3} ; \mathrm{B}$ - Modulus of Rupture (MOR) / čvrstoća loma, MPa; C - Modulus of Elasticity $(M O E)$ / modul elastičnosti, GPa; D - Compression parallel to grain / tlačna čvrstoća paralelno s vlakancima, MPa; E - cross-section hardness / tvrdoća na poprečnom presjeku, MPa; F - radial hardness / tvrdoća na radijalnom presjeku, $\mathrm{MPa}$; $\mathrm{G}$ - compression perpendicular to grain / tlačna čvrstoća okomito na vlakanca, $\mathrm{MPa}$ 
... Kiaei, Abadian: Physical and Mechanical Properties of Hornbeam Wood from Dominant...

Table 4 Mechanical properties of hornbeam wood

Tablica 4. Mehanička svojstva drva graba

\begin{tabular}{|l|c|c|}
\hline $\begin{array}{l}\text { Mechanical properties } \\
\text { Mehanička svojstva }\end{array}$ & $\begin{array}{c}\text { Suppressed } \\
\text { Potisnuta stabla }\end{array}$ & $\begin{array}{c}\text { Dominant } \\
\text { Dominantna stabla }\end{array}$ \\
\hline$M O R, \mathrm{MPa}$ & $153.5 \mathrm{~b}$ & $140.9 \mathrm{a}$ \\
\hline$M O E, \mathrm{GPa}$ & $14.76 \mathrm{a}$ & $14.70 \mathrm{a}$ \\
\hline $\begin{array}{l}\text { Compression strength parallel to grain, } \mathrm{MPa} \\
\text { Tlačna čvrstoća paralelno s vlakancima, } \mathrm{MPa}\end{array}$ & $63.20 \mathrm{a}$ & $64.5 \mathrm{~b}$ \\
\hline $\begin{array}{l}\text { Compression strength perpendicular to grain, MPa } \\
\text { Tlačna čvrstoća okomito na vlakanca, MPa }\end{array}$ & $9.70 \mathrm{a}$ & $11.5 \mathrm{~b}$ \\
\hline Hardness in cross-section, MPa / Tvrdoća na poprečnom presjeku, MPa & $91.8 \mathrm{a}$ & $97.8 \mathrm{~b}$ \\
\hline Hardness in radial-section, MPa / Tvrdoća na radijalnom presjeku, MPa & $75 \mathrm{a}$ & $84.1 \mathrm{~b}$ \\
\hline
\end{tabular}

tively. The average MOR is higher in suppressed trees than in dominant tress (Table 4). The mean MOR in suppressed and dominant trees is higher than in other sites in Iran such as Golestan (Golbabaei et al., 2004), Veysar-Mazandran (Hossinzade et al., 2000), and Asalom Guilan (Golbabeai et al., 2001) (Table 3).

\subsubsection{Modulus of elasticity (MOE) \\ 3.2.2. Modul elastičnosti (MOE)}

T-test analysis indicated that the effect of suppressed-dominant trees on the MOE was not significant. The average MOE in suppressed and dominant trees was 14.76 and $14.70 \mathrm{GPa}$, respectively. This average MOE is higher in suppressed trees than in dominant tress (Table 4). The mean MOE of hornbeam wood in suppressed and dominant trees is higher than in Golestan site (Golbabaei et al., 2004), lower than in Asalom Guilan site (Golbabaei et al., 2001) and similar to Veysar-Mazandran site (Hossinzade et al., 2000; Table 3).

\subsubsection{Compression parallel to the grain}

\subsubsection{Tlačna čvrstoća paralelno s vlakancima}

T-test analysis indicated that the effect of suppressed-dominant trees on the compression parallel to the grain of hornbeam wood was significant. The average compression parallel to the grain in suppressed and dominant trees was 63.20 and $64.50 \mathrm{MPa}$, respectively. This average is lower in suppressed trees than in dominant tress (Table 4). The mean compression parallel to the grain in suppressed and dominant trees is higher than in other sites in Iran such as Veysar-Mazandran (Hossinzade et al., 2000), and Asalom Guilan (Golbabaei et al., 2001) sites, lower than Golestan (Golbabaei et al., 2004 - intermediate altitude) and Turkish sites (Gunduz et al., 2009), and similar to Golestan site (high altitude, Golbabaei et al., 2004; Table 3).

\subsubsection{Compression strength perpendicular to the grain \\ 3.2.4. Tlačna čvrstoća okomito na vlakanca}

T-test analysis indicated that the effect of suppressed-dominant trees on the compression perpendicular to the grain of hornbeam wood was significant. The average compression perpendicular to the grain in suppressed and dominant trees was 9.70 and 11.50 $\mathrm{MPa}$, respectively (Table 4). This average of hornbeam wood is lower in suppressed trees than in dominant tress. The mean compression perpendicular to the grain in suppressed and dominant trees is lower than in Golestan (Golbabaei et al., 2004, high and intermediate altitude; Table 3 ).

\subsubsection{Cross section hardness}

\subsubsection{Tvrdoća na poprečnom presjeku}

T-test analysis indicated that the effect of suppressed-dominant trees on the hardness of hornbeam wood in cross-section was significant. The average hardness in cross-section in suppressed and dominant trees was 91.8 and $97.8 \mathrm{MPa}$, respectively. This average is lower in suppressed trees than in dominant tress (Table 4). The average hardness (cross-section) is higher than that of Turkish hornbeam wood (Gunduz et al., 2009; Table 3).

\subsubsection{Radial hardness}

3.2.6. Tvrdoća na radijalnom presjeku

T-test analysis indicated that the effect of forestry mass on the hardness in radial section of hornbeam wood was significant. The average hardness in radialsection in suppressed and dominant trees was 75 and 84.1 $\mathrm{MPa}$, respectively. This average is lower in suppressed trees than in dominant tress (Table 4). The average hardness (radial section) is higher than that of Turkish hornbeam wood (Gunduz et al., 2009; Table 3).

\subsection{Wood mechanical quality}

3.3. Klasifikacija mehaničke kvalitete drva

According to the static quality index (SQV), wood quality can be classified as low, fair and good (Bektas et al., 2002; Korkut and Guller, 2008). In this case, SQV $<7$ is low quality, $7<\mathrm{SQV}<8.5$ is fair quality, and $8.5<\mathrm{SQV}$ is good quality. Static quality index in dominant trees was 8.32 , and in suppressed trees it was 8.26. This index is higher in dominant trees than in suppressed trees. According to this classification, the Iranian hornbeam wood in suppressed and dominant trees falls under the second category (fair category).

According to the static bending index (Parsapajouh, 1998), wood quality can be classified as weak index (between 10 and 15), fair index (between 15 and 20) and resistance index (between 20 and 25). This index in suppressed and dominant trees was 20 and 18.18. According to this classification, the Iranian hornbeam wood in suppressed and dominant trees falls under the second category (fair quality). This index is lower in dominant trees than in suppressed trees. 
According to the strong quotation (Parsapajouh, 1998), wood quality can be classified as low tolerance (less than 2), fair (between 2 and 3 ) and resistance index (between 3 and 4). This index in suppressed and dominant trees was 2.42 and 2.18 , respectively. This index is lower in dominant trees than in suppressed trees. According to this classification, the Iranian hornbeam wood in suppressed and dominant trees falls under the second category (fair quality index).

Another classification according to the strong quotation was reported by Bektas et al., (2002) and Korkut and Guller, (2008). They reported that for an ordinary wood species, according to the strong quotation value, the ratio between static bending strength and compression strength is considered to be 1.75 . In the present study, it was found that the calculated index for dominant and suppressed trees was higher than 1.75.

Another criterion for the evaluation of wood properties is the value of $\mathrm{q}$, a ratio between compression strength and density (Korkut and Guller, 2008; Bektas et $a l ., 2002$,). Each wood species has a specific q value but there is no adequate classification; nevertheless, this value is used to compare the wood with other non-wood materials and it is used in some calculations for industrial applications. According to this criterion, the $\mathrm{q}$ index in dominant and suppressed trees was 888 and 859 , respectively. This index is higher for hornbeam wood from trees grown in dominant stands than hornbeam wood from trees grown in suppressed stands.

In mixed forests, suppressed trees had higher modulus of rupture (MOR) and modulus of elasticity (MOE) and lower compression parallel to the grain, compression perpendicular to the grain, impact strength and hardness (in cross-section and radial section) than dominant trees. In diffuse porous hardwood such as hornbeam, anatomical properties play an important role in the variation of mechanical properties. It is necessary to know its anatomical properties to predict the mechanical behavior of wood.

\section{CONCLUSION}

\section{ZAKLJUČAK}

In this study, differences between hornbeam wood from trees grown in dominant stands and hornbeam wood from trees grown in suppressed stands were investigated. The following conclusions were drawn from this research:

1- Statistical results indicated that there are significant differences in mechanical properties of hornbeam wood (except MOE) from trees grown in suppressed and dominant stands. Suppressed-dominant trees had no significant effects on physical properties of hornbeam wood.

2- The average MOE (about $0.4 \%$ ) and MOR (about $8.94 \%$ ) of hornbeam wood are higher in suppressed trees than in dominant trees. The averages of compression parallel to the grain $(2.05 \%)$, compression perpendicular to the grain $(18.55 \%)$, hardness in cross-section $(6.53 \%)$ and hardness in radial section $(12.13 \%)$ of hornbeam wood are higher in dominant trees than in suppressed trees.
3- According to mechanical indices, wood quality of hornbeam wood from trees grown in dominant stands and hornbeam wood from trees grown in suppressed stands was fair.

\section{REFERENCES}

\section{LITERATURA}

1. Bektas, I.; Guler, C.; Busturk, M., 2002: Principal Mechanical Properties of Eastern Beech Wood (Fagus orientalis Lipsky) Naturally Grown in Andirin Northeastern Mediterranean Region of Turkey. Turkish Agriculture and Forestry 26: 147-154.

2. Garmaroody, E. R.; Resalati, H.; Fardim, P., 2012: Modification of kraft pulp fibers by fungal pre-treatment of Iranian hornbeam chips. International Biodeterioration and Biodegradation, 70: 20-26.

https://doi.org/10.1016/j.ibiod.2011.12.012.

3. Golbabaei, F.; Hossinzade, A.; Hossinkhani, H.; Fakhriyan, A., 2001: Variation of wood properties of hornbeam in three altitudes above sea level of Guilan forest. Iranian Journal of Wood and Paper Research, 15: $33-59$ [in Persian].

4. Golbabaei, F.: Nourbakhsh, A.; Fakhriyan, A.; Falahdoust, S. H., 2004: Variation of wood properties of hornbeam in two altitudes above sea level of Golestan forest. Iranian Journal of Wood and Paper Research, 19: 258287 [in Persian].

5. Gunduz, G.; Korkut, S.; Aydemir, D.; Bekar, I., 2009: The density, compression strength and surface hardness of heat treated hornbeam (Carpinus betulus) wood. Maderas. Ciencia y tecnología, 11 (1): 61-70. https://doi.org/10.4067/S0718-221X2009000100005.

6. Hossinzade, A.; Toghraei, N.; Golbabaei, F.; Nourbakhsh, A., 2000: Variation of physical and mechanical properties of hornbeam in Veysar - Mazandaran site. Iranian Journal of Wood and Paper Research, 9: 109-149 [in Persian].

7. Jalali, S. G.; Hosseini, S. M.; Akbarinia, M.; Rabi, B., 2003: A comparative study of pure and mixed plantation of poplar in terms of production of wood quality and quantity. Pajouhesh and Sazandegi, 16 (1): $82-88$ [in Persian].

8. Kabiri, K.; Marvie Mohadjer, M. R.; Zahedi Amiri, G. H.; Namiranian, N.; Etemad, V., 2009: A comparison on the quantitative and qualitative morphological characteristics of beech (Fagus orientalis Lipsky) in a pure and mixed stand (Gorazbon district, North of Iran). Iranian Journal of Forest and Poplar Research, 17 (3): 422-435 [in Persian].

9. Kiaei, M., 2013: Effect of cultivation methods on wood static bending properties in Alnus glutinosa. Drvna industrija, 64 (4) 265-271. https://doi.org/10.5552/drind.2013.1240.

10. Kiaei, M., 2012: Effect of site and elevation on wood density and shrinkage and their relationships in Carpinus betulus. For. Stud. China, 14 (3): 229-234. https://doi.org/10.1007/s11632-012-0310-3.

11. Korkut, S.; Guller, B., 2008. Physical and mechanical properties of European Hophornbeam (Ostrya carpinifolia Scop.) wood. Bioresource Technology, 99: 47804785. https://doi.org/10.1016/j.biortech.2007.09.058.

12. Kozlowski, T. T.; Peterson, T. A., 1962: Seasonal Growth of Dominant, Intermediate and Suppressed Red Pine Trees. Botanical Gazette, 124 (2): 146-154. http://www.jstor.org/stable/2473051. 
... Kiaei, Abadian: Physical and Mechanical Properties of Hornbeam Wood from Dominant...

13. Makhmalbaf, N.; Khademi-Eslam, H.; Hemmasi, A. H.; Bakhshi, R., 2007: An investigation on the relationship between stem size and longitudinal growth strains in hornbeam species (Carpinus betuluse). Ph. D. Thesis, Science and Research Branch, Islamic Azad University, Tehran, Iran.

14. Nasernakheai, M.; Makhtomi, A.; Shafieaifar, S., 1997: Investigation on the mechanical properties of Iranian hornbeam wood (case study in Sangdeh-Sari). Research plan of Iranian Forests and Rangelands. No: 99 [in Persian].

15. Parsapajouh, D., 1998: Wood Technology. $4^{\text {th }}$ ed. Tehran University, No: 1851, Iran.

16. Rathgeber, C. B. K.; Rossi, S.; Bontemps, J. D., 2011: Cambial activity related to tree size in a mature silver-fir plantation. Annals of Botany, 108: 429-438. https://doi.org/10.1093/aob/mcr168.

17. Rouhi Moghaddam, A.; Ebrahimi, E.; Hosseini, S. M.; Rahmani, A.; Tabari, M., 2009: Comparison of growth characteristics of oak in pure and mixed plantations A. Iranian Journal of Forest and Poplar Research, 17 (2): 210-224 [in Persian].
18. Sabeti, H., 2008: Iranian trees and shrub. $5^{\text {th }}$ ed. Yazd Publication.

19. Sayad, E.; Hosseini, S. M.; Mokhtari, J.; Mahdavi, R., 2006: Comparison of growth and qualitative properties in pure and mixed plantations of Populous deltoids Marsh and Alnus subcordata mey. Pajouhesh and Sazandegi, 71: $2-10$.

\section{Corresponding address:}

Assoc. Prof. MAJID KIAEI, Ph.D.

Department of Wood and Paper Science

and Technology

Chalous Branch

Islamic Azad University

Chalous, IRAN

e-mail: Mjd_kia59@yahoo.com, Mjd-kia59@iauc.ac.ir 